\title{
ANALISIS EFEKTIFITAS DAN KONTRIBUSI PAJAK BUMI DAN BANGUNAN PEDESAAN DAN PERKOTAAN (PBB-P2) TERHADAP PENINGKATAN PENERIMAAN PENDAPATAN ASLI DAERAH DI KABUPATEN MINAHASA SELATAN DAN KOTA MANADO
}

\author{
Felia Lintong $^{1}$, Harijanto Sabijono ${ }^{2}$, Meily Y. B. Kalalo ${ }^{3}$ \\ ${ }^{2,3}$ Jurusan Akuntansi, Fakultas Ekonomi dan Bisnis, Universitas Sam Ratulangi, Jl. Kampus Bahu, Manado, \\ 95115, Indonesia \\ E-mail : lintongfelia@gmail.com
}

\begin{abstract}
Basically Tax is a levy or a contribution to the state and also the main source of income from taxes. Law no. 12 Year 1985 is the basis of collecting Land and Building Tax, while Land Tax and Rural and Urban Buildings are potential for the revenue of local origin. The purpose of this study was to determine the effectiveness and contribution of land taxes and rural and urban buildings in South Minahasa District and Manado City. The research used is a qualitative descriptive method. The research data is collected by direct interviews with the parties concerned and by literature study. The results showed that the effectiveness of tax revenue earth and rural and urban buildings South Minahasa District $88.12 \%$ (quite effective), and Manado City $95.52 \%$ (effective). The contribution of the land tax and rural and urban buildings to the local revenue of South Minahasa Regency is $4.55 \%$ (very less), and Manado City is $9.46 \%$ (very less).
\end{abstract}

Keywords: PBB-P2, income, effectiveness, and contribution

\section{PENDAHULUAN}

Negara Indonesia ialah negara hukum berlandaskan Pancasila serta UUD 1945 yang menjunjung tinggi hak dan kewajiban setiap orang. Oleh sebab itu, perpajakan sebagai salah satu wujud dari kewajiban kenegaraan dalam kegotongroyongan nasional sesuai peran serta masyarakat untuk membantu pembangunan. Seperti dengan ketentuan pasal 23 ayat 2 UUD 1945, ketentuan tentang perpajakan yang merupai landasan tentang dipungutnya pajak yang diatur oleh undang-undang. Undang-undang nomor 12 tahun 1994 tentang perubahan undang-undang nomor 12 tahun 1985 tentang Pajak Bumi dan Bangunan merupakan landasan hukum pajak berhubung dengan hak atas bumi dan perolehan manfaat atas bumi dan mempunyai hak atas penguasaan serta perolehan manfaat atas pembangunan. Pajak ialah sumber pemasukan negara yang paling besar. Peran pajak sebagai pemasukan untuk negara sebagai penyelaras kegiatan ekonomi untuk masa yang akan datang sangat penting bagi negara kita. Agar dapat mencapainya, pemerintahan akan melakukan upaya dalam pajak untuk menyadari peran serta masyarakat sebagai WP untuk menyanggupi kewajiban perpajakannya.

Pendapatan Asli Daerah memiliki komponen yang sangat penting dikarenakan cerminan dari kemandirian daerah untuk membiayai aktifitas untuk sumber PAD. Pajak Bumi dan Bangunan adalah salah satu sumber pendapatan daerah yang asalnya oleh dana perimbangan. PBB wajib dikelolah dengan baik untuk mencapai langkah yang efektif untuk harapan agar meningkatkan PAD. UU Nomor 33 Tahun 2004 tentang Perimbangan Keuangan dari pemerintahan pusat serta daerah untuk memberi lebih banyak lagi wewenang kepada daerah untuk melaksanakan fungsi pemerintah untuk membuat sumber pendapatan daerah sebagai wujud dari terlaksananya otonomi daerah. Konsep itu berdampak pada 
pemerintah pusat yang tidak sepenuhnya lepas tanggung jawab terhadap keuangan daerahnya. Tujuan dari pada penelitian ini yakni untuk melihat tentang hasil analisis efektifitas dan kontribusi PBB pedesaan dan kota yang berada di Kabupaten Minahasa Selatan dan Kota Manado.

\section{TINJAUAN PUSTAKA}

Akuntansi. Menurut Accounting Principle Board dalam Sodikin dan Riyono (2014:1), akuntansi ialah kegiatan jasa. Berfungsi untuk memberikan informasi kuantitatif, dan serta bersifat keuangan, dan entitas ekonomi yang ditujukan supaya berguna untuk mengambil keputusan ekonomi serta pengambilan pilihan beralasan antara banyaknya tindak alternatif. Menurut Diana Sari (2017:2), akuntansi adalah sebuah proses untuk menghasilkan informasi bagi para pengguna yang biasanya dalam bentuk laporan keuangan. akuntansi adalah sistem informasi yang dapat dipertanggungjawabkan untuk memberi laporan yang berhubungan dengan keuangan kepada pihak yang membutuhkan serta memberikan informasi tentang kondisi perusahan secara ekonomi yang berguna dalam pengambilan keputusan ekonomi. Akuntansi ialah aktivitas proses untuk pengidentifikasikan, pencatatan, pengklasifikasikan, pengolah serta penyajian data yang sehubungan dengan laporan keuangan serta transaksi supaya mudah untuk dimengerti dalam pengambilan keputusan yang sesuai. (Rudianto 2015:2).

Pajak. Akuntansi pajak adalah bagian dari akuntansi yang muncul dari unsur spesialisas yang dituntut keahlian dalam bidang tertentu. Akuntansi pajak ada dikarenakan adanya suatu prinsip dasar yang dibuat oleh undang-undang pajak serta pembentuknya dipengaruhi dari fungi pajak untuk menerapkan sesuai peraturan pemerintahan. Tujuan akuntansi pajak untuk menentukan besar pajak terutang sesuai laporan keuangan yang dibuat oleh perusahaan (Agoes, 2013:10). Akuntansi perpajakan meliputi penyusunan Surat Pemberitahuan Pajak (SPT), serta mempertimbangkan konsekuensi perpajakan dari transaksi usaha yang direncanakan atau mencari alternatif pelaksanaan terbaik. Seorang akuntan yang mengambil spesialisasi dalam bidang ini, terutama dalam hal perencanaan mengenai pajak, harus mengenai jenis pajak yang mempengaruhi perusahaan. Selain itu akuntan harus mengetahui peraturan perpajakan yang terbaru serta keputusan-keputusan pengadilan menyangkut kasus perpajakan (Sadeli, 2016:6).

Pajak Bumi dan Bangunan Perdesaan dan Perkotaan. Pajak Bumi dan Bangunan Perdesaan dan Perkotaan (PBB_P2) ialah bumi dana atau bangunan yang dimiliki, dikuasai, dan/atau fungsi buat orang pribadi atau badan, selain area yang berguna buat kegiatan usaha perkebunan, perhutanan dan pertambangan, dan cara khusus lainnya yang diminta dari pemerintah pusat (Mardiasmo, 2016:406). Dari berlakunya Undang-Undang Nomor 28 Tahun 2009 tanggal 15 September mengenai Pajak Daerah dan Retribusi Daerah, kewenangan untuk memunguti Pajak Bumi dan Bangunan sektor pedesaan dan perkotaan diberikan ke pemerintah kabupaten/kota. Pengalihan pengelolahan Pajak Bumi dan Bangunan (PBB) Perdesaan dan Perkotaan untuk pemerintah kabupaten/kota semenjak 1 Januari dan paling lambat 1 Januari 2014.

Syarat Pemungutan Pajak. Tidak gampang memberikan pajak pada masyarakat. Jika terlalu berlebihan atau terlalu tingi maka masyarakat akan berat hati membayar pajak, tetapi jika terlalu rendah, maka pembentukan tidak akan berjalann lancar. Maka agar pengambilan pajak tidak memicu gangguan atau perlawanan, maka pengambilan pajak harus memenuhii syarat berikut:

1. Pemungutan pajak harus adil (Syarat Keadilan). Sesuai dengan arah hukum, yaitu menggapai keadilan, undang-undang ataupun yang melaksanakan pemungutan pajak harus adil. Adil dalam undang-undang antaranya menggunakan pajak menurut ketentuan yang adil, dan disesuaikan dengan kemampuan tiap masyarakat. 
2. Memungut pajak juga berdasarkan undang-undang (Syarat Yuridis). Di Indonesia, pajak diatur berdasarkan UUD 1945 pasal 23 ayat 2. Keadaan ini memberikann tangguhan hukum untuk memberitahukan keadilan, baik menurut negara maupun warganya.

3. Tidak mengganggu perekonomian (Syarat Ekonomis). Pemungutan tidak boleh menunggu kelancaran aktivitas produksi maupun perdagangan, sehingga tidak melahirkan kelambanan perekonomian masyarakat.

4. Pemungutan pajak harus efisien (Syarat Finansil). Sesuai fungsi budgetair, biaya yang dipungut pajak layak lebih rendah dari hasil pungutannya.

5. Sistem pemungutan pajak harus sederhana. Sistem pungutan yang gampang akan lebih mudah dan membawa masyarakat pada memenuhi komitmen perpajakannya. Kondisi ini juga dipenuhi oleh undang-undang perpajakan yang baru. Contoh:

a. Bea Meterai dibuat sederhana dari 167 tarif menjadi 2 tarif.

b. Jumlah PNN yang banyak dibuat sederhana menjadi 1 tarif, yaitu $10 \%$.

c. Pajak perseroan pada badan dan pajak pendapatan buat perseroan yang dibuat sederhana menjadi pajak penghasilan (PPh) yang resmi bagi badan maupun perseorangan (Samudra, 2015: 264)

Pendapatan Asli Daerah. Pengertian Pendapatan Asli Daerah berlandaskan UndangUndang Nomor 33 Tahun 2004 atas Perimbangan Keuangan antara Pusat dan Daerah Pasal 1 angka 18 bahwa "Pendapatan asli daerah, selanjutnya disebut PAD adalah pendapatan yang diperoleh daerah yang dipungut berdasarkan peraturan daerah sesuai dengan peraturan perundang-undangan". Pendapatan Asli Daerah (PAD) yaitu hasil daerah yang sumbernya dari hasil pajak daerah, hasil retribusi Daerah, hasil yang dikelola kekayaan daerah yang terpisah, dan lain-lain pendapatan Asli daerah yang sah, yang bertujuan buat menunjukan kekuasaan untuk daerah yang menggali dana dalam penerapan otonomi daerah untuk mewujudkan asas desentralisasi. Pendapatan Asli Daerah yang disebut juga PAD, yakni penerimaan yang beroleh dari daerahh yakni dari dalam wilayahnya itu sendri yang diambil dari Peraturan Daerah sesuai dengan peraturan undang-undangan yang berlaku pada pasal 1 Undang-Undang Nomor 33 Tahun 2004. Maka demikian Pendapatan Asli Daerah merupakan sumber dari pendapatan yang benar berasal dari potensi daerah. Pemerintah daerah dapat mendapatkan sumberr Pendaptan Asli Daerah itu secara optimal.

Konsep Pajak Daerah. Pajak daerah yakni kontribusi wajib buat daerah yang berhutang oleh orang pribadi atau badan yang bersifat memaksa berdasarkan undang-undang atas tidak mendapatkan balasan secara langsung dan digunakan untuk keperluan daerah untuk sebesar-besarnya kemakmuran rakyat. Dasar dari hukum baru untuk pajak daerah dan retribusi daerah Undang-Undang Nomor 28 Tahun 2009 tanggal 15 September 2009 tentang Pajak Daerah dan Retribusi Daerah (Lembaran Negara Republik Indonesia Tahun 2009 Nomor 130 Tambahaan Lembaran Negara Republik Indonesia No 5049. Pajak atau kontribusi wajib yaitu diberikan buat penduduk suatu daerah kepada pemerintah daerah ini akan dibuat untuk kepentingan pemerintah dan kepentngan banyak orang suatu daerah. Selain untuk pembangunan suatu daerah, pajak daerahh yang diterima merupakan salah satu sumber Anggaran Pendapatan Daerah (APBD) yang diguunakan pemerintah untuk menjalankan program-program kerjanya.(Mardiasmo,2016:1).

Dasar Hukum Pemungutan PBB-P2. Dasar Hukum: Undang-Undang Nomor 28 tahun 2009 tentang Pajak Daerah dan Retribusi Daerah (PDRD). Disesuaikan dengan UU Nomor 28 Tahun 2009 mengenai PDRD bahwa paling lama 1 Januari 2014 PBB dan Bangunan Sektor Perdesaan dan Perkotaan (PBB-P2) akan berpindah pengelolaannya yang dikelola Direktorat Jendral Pajak (DJP), Kementerian Keuangan Republik Indonesia akan berpindah kepada Pemerintah Kabupaten/Kota, dan PBB sektor Perkebunan, Perhutanan dan Pertambangan (P3) akan menjadi pusat Pajak. Dasar hukum pengambilan PBB-P2 pada Kabupaten/Kota ialah seperti berikut: 
1. UU Nomor 28 Tahun 2009 mengenai PDRD.

2. Aturan Daerah Kabupaten/Kota yang mengatur mengenai Pajak Bumi serta Bangunan Perdesaan dan Perkotaan.

3. Putusan Bupati/Walikota yang mengatur tentang Pajak Bumi dan Bangunan Perdesaan dan Perkotaan sesuai pengaturan pelaksana Peraturan Daerah mengenai Pajak Bumi serta Bangunan Perdesaan dan Perkotaan untuk Kabupaten/Kota yag dituju.

Efektifitas. Efektifitas yaitu suatu keadaan yang menunjukkan sejauh mana rencana dapat tercapai. Efektivitas dipakai untuk menghitung hubungan antara jumlah pengutan suatu pajak dengan tujuan atau target yang telah ditetapkan. Efektifitas dapat pula dikatakan sebagai pengukuran keberhasilan dalam mencapai tujuan-tujuan yang telah ditentukan. Efektifitas ialah sumber daya, sarana dan prasarana dalam jumlah tertentu yang secara pasti ditentukan untuk hasil jumlah supaya mencapai sejumlah barang atas kegaitian yang dituju. (Warren 2014:16).

Kontribusi. Kontribusi adalah besaran sumbangan yang diberikan atas sebuah kegiatan yang dilaksanakan. Kontribusi dalam pajak daerah ialah sebagaimana jumlah dana yang dikumpul oleh sector pajak di suatu daerah dibanding jumlah hasil penerimaan daerah. Kontribusi dalam PBB-P2 adalah suatu nilai untuk mengetahui tingkat kontribusi yang dihitung berdasarkan persentase perbandingan realisasi penerimaan PBB-P2 dengan realisasi (PAD). (Warren 2014:17).

Penelitian Terdahulu. Rany Nurmala sari (2014) dalam penelitian Analisis efektivitas dan kontribusi proses pelayanan pengalihan pengelolaan serta pemasukan Pajak Bumi dan Bangunan terhadap pendapatan daerah. Hasil penelitian menunjukan bahwa untuk pemasukan PBB dari tahun 2009-2013 meningkat. Kontribusi terhadap PAD lebih mengalami penurunan. Efektivitas peralihan dikelola organisasi telah berjalan efektif dan dengan matriks pengalihan dari DJP dan dikaitkan langsung teori efektifitas. Napitupulu (2017) dalam penelitian "Pajak Bumi dan Bangunan Perdesaan dan Perkotaan (PBBP2) sebagai pajak daerah dan Implikasinya terhadap pencatatan akuntansi pada pemerintah Kota Manado". Hasil penelitian beranggapan bahwa penerapan pemungutan PBB-P2 di Dispenda Kota Manado, secara umum berjalan dengan baik meski ada beberapa kendala yang terjadi dikarenakan ini merupakan tahun pertama pelaksanaan.

\section{METODE PENELITIAN}

Jenis Penelitian. Jenis penelitian yang digunakan dalam penelitian ini yaitu penelitian deskriptif dengan pendekatan kualitatif.

Tempat dan Waktu Penelitian. Observasi ini di laksanakan di Kantor Badan Pengelola Pajak dan Retribusi Daerah Kabupaten Minahasa Selatan, Kantor Pengelola Pajak dan Retribusi Daerah Kota Manado. Periode waktu penelitian dimulai pada Bulan Maret 2018.

Jenis Data. Dalam penulis melaksanakan analisis juga pembahsan terhadap masalah-masalah yang terjadi dalam penelitian ini penulis menggunakan 2 data yaitu, data kualitatif dan data kuantitatif.

Sumber data. Sumber data dibedakan atas dua jenis, yaitu:

1. Data Primer. Data primer ialah data yang didapat secara langsung individu serta perorangan dan dibutuhkan pengelolaan lebih dalam sesuai dari wawancara dan hasil pengisian kuesioner. Data primer yang dibuat oleh penulis merupai hasil dari wawancara seperti Tanya jawab dengan pihak tersebut. Dalam penelitian ini data primer yang digunakan adalah target dan realisasi PBB-P2, serta target dan realisais PAD Kabupaten Minahasa Selatan.

2. Data Sekunder. Data Sekunder ialah data primer yang sudah diolah lebih dalam serta dibuat baik untuk pihak pengumpulan data primer atau pihak lain-lain. Dalam penelitian 
ini data sekunder yang digunakan adalah berapa Jumlah Objek Pajak Bumi dan Bangunan

Pedesaan dan Perkotaan Kabupaten Minahasa Selatan.

Dalam penelitian ini sumber data yang digunakan adalah data primer yang diperoleh dari hasil wawancara langsung dengan Kantor Badan Pengelola Pajak dan Retribusi Daerah (BPPRD)Kabupaten Minahasa Selatan, Kantor Badan Pendapatan Keuangan dan Aset Daerah (BPKAD) Kabupaten Minahasa Selatan, dan Kantor Pelayanan Pajak Kabupaten Minahasa Selatan.

Teknik Pengumpulan Data. Dalam proses pengumpulan data yang diperlukan, penulis menggunakan 2 (dua) teknik/metode pengumpulan data yaitu:

- Interview, untuk wawancara untuk penelitian seperti tanya jawab untuk pemimpin dan karyawan yang ditunjukan mengadakan peneliti seperti tata cara penglaporan serta mengenai masalah tersebut.

- Dokumenter, teknik pengumpulan data untuk membuat arsip serta dokumen untuk perusahaan yang bersangkutan.

- Penelitian perpustakaan, Penelitian kepustakaan atau penelitian perpustakaan yang penelitiannya dilakukan di perpustakaan dengan mengumpulkan buku-buku yang menjadi refrensi untukmenulis.

Metode Proses Analisis. Metode yang dibuat penulis adalah membahas masalah untuk peneliti ini ialah metod analisis deskriptif kualitatif adalah metode untuk cara membuat pernyataan serta keadaan untuk suatu objek dalam bentuk uraian kalimat yang mendasari keterangan untuk pihak yang sehubungan resmi sesuai observasi ini. Adapun tahapan analisis data yang digunakan dalam penelitian ini adalah sebagai berikut.

Analisis Efektifitas. Alat untuk mengetahui efektivitas, akan dipakai indikator seperti ini:

Tabel 1. Klasifikasikan Pengukuran Efektivitas

\begin{tabular}{cc}
\hline Persentase & Kriteria \\
\hline$>100 \%$ & Sangat efektif \\
$90-100 \%$ & Efektif \\
$80-90 \%$ & Cukup efektif \\
$60-80 \%$ & Kurang efektif \\
$<60 \%$ & Tidak efektif \\
\hline
\end{tabular}

Sumber: Depdagri, Kepmendagri No.690.900.327 (Rima Adelina, 2013)

Analisis Kontribusi. Alat untuk mengetahui kontribusi, akan pakai indikator seperti ini:

Tabel 2. Klasifikasi Kriteria Kontribusi

\begin{tabular}{cc}
\hline Persentase & Kriteria \\
\hline $0,00 \%-10 \%$ & SK \\
$10,10 \%-20 \%$ & K \\
$20,10 \%-30 \%$ & S \\
$30,10 \%-40 \%$ & CB \\
$40,10 \%-50 \%$ & B \\
Diatas $50 \%$ & SB \\
\hline
\end{tabular}

Sumber: Depdagri, Kepmendagri No.690.900.327 (Rima Adelina,2012)

Ket: SK (Sangat Kurang), K (Kurang), S (Sedang), CB (Cukup Baik), B (Baik), SB (Sangat Baik) 
4. HASIL ANALISIS DAN PEMBAHASAN

4.1. Pendapatan Asli Daerah Kabupaten Minahasa Selatan dan Kota Manado

Tabel 3 Target dan Realisasi PBB-P2 Kabupaten Minahasa SelatanTahun 2015-2017

\begin{tabular}{|c|c|c|}
\hline Tahun & $\begin{array}{l}\text { Target } \\
(\mathbf{R p})\end{array}$ & $\begin{array}{l}\text { Realisasi } \\
\text { (Rp) }\end{array}$ \\
\hline 2015 & 3.000 .000 .000 & 1.182 .675 .827 \\
\hline 2016 & 2.500 .000 .000 & 2.379.297.962 \\
\hline 2017 & 520.000 .000 & 674.609 .264 \\
\hline
\end{tabular}

( Sumber: Data Badan Pengelola Pajak dan Retribusi Daerah Kabupaten Minahasa Selatan)

Berdasarkan Tabel 3 menunjukan bahwa target PBB-P2 Kabupaten Minasa Selatan tahun 2015 sebesar Rp3.000.000.000 dan realisasi hanya sebesar Rp1.182.675.827. Pada tahun 2016 target sebesar 2.500.000.000 dan realisasi 2.379.297.962. Di tahun 2017 realisasinya lebih tinggi dari target, target PBB-P2 sebesar 520.000.000 dan realisasi 674.609.264.

Tabel 4 Target dan Realisasi PBB-P2 Kota ManadoTahun 2015 - 2017

\begin{tabular}{ccr}
\hline Tahun & $\begin{array}{c}\text { Target } \\
(\mathbf{R p})\end{array}$ & $\begin{array}{c}\text { Realisasi } \\
(\mathbf{R p})\end{array}$ \\
\hline 2015 & $31.210 .524 .776,00$ & $28.740 .333 .816,00$ \\
2016 & $30.000 .000 .000,00$ & $24.467 .264 .925,00$ \\
2017 & $24.534 .660 .000,00$ & $27.710 .018 .490,00$ \\
\hline
\end{tabular}

( Sumber: Data Badan Pengelola Pajak dan Retribusi Daerah Kota Manado)

Berdasarkan Tabel 4 menunjukan bahwa target PBB-P2 Kota Manado tahun 2015 sebesar Rp 31.210.524.776,00 dan realisasi sebesar Rp 28.740.333.816,00. Pada tahun 2016 sebesar Rp 30.000.000.000,00 dan realisasi sebesar Rp 24.467.264.925,00. Dan pada tahun 2017 sebesar Rp 24.534.660.000,00 dan realisasi sebesar $\mathrm{Rp} 27.710 .018 .490,00$.

Efektivitas Penerimaan PBB-P2 Kabupaten Minahasa Selatan dan Kota Manado.

Tabel 5. Efektivitas Penerimaan PBB-P2 Kabupaten Minahasa Selatan tahun 2015-2017

\begin{tabular}{cccrl}
\hline Tahun & $\begin{array}{c}\text { Target } \\
(\mathbf{R p})\end{array}$ & $\begin{array}{c}\text { Realisasi } \\
(\mathbf{R p})\end{array}$ & $\begin{array}{c}\text { Persentase } \\
(\boldsymbol{\%})\end{array}$ & Kriteria \\
\hline 2015 & $3.000 .000 .000,00$ & $1.183 .675 .827,00$ & $39,46 \%$ & Kurang efektif \\
2016 & $2.500 .000 .000,00$ & $2.379 .297 .962,00$ & $95,17 \%$ & Efektif \\
2017 & $520.000 .000,00$ & $674.609 .264,00$ & $129,73 \%$ & Sangat efektif \\
& Rata-rata & & $88,12 \%$ & Cukup efektif \\
\hline (Sumber: & Data & Badan Pengelola & Pajak dan Retribusi & Daerah Kabupaten Minahasa \\
Selatan) & & & &
\end{tabular}

Berdasarkan Tabel 5 menunjukan tingkat efektifitas PBB-P2 pada tahun 2015 dengan persentase 39,46\% Kurang efektif, dikarenakan tingginya target pendapatan dalam membayar pajak namun dalam realisasinya sangat menurun drastis. Masyarakat perdesaan contohnya masih banyak yang kurang mengerti dalam membayar pajak dan masih banyak juga masyarakat yang kurang mengerti kegunaan kita atau manfaat kita dalam membayar pajak, sehingga pada tahun berikutnya pada Tahun 2016 pemerintah pada awal tahun melakukan sosialisasi pada masyarakat-masyarakat yang ada di perdesaan dan di kelurahan. Pada tahun 
2016 pemerintah menurunkan target sehingga persentase pada tahun 2016 yaitu 95,17\%. Menunjukan bahwa sosialisasi yang dilakukan oleh pemerintah pada awal tahun menunjukan kemajuan yang baik sehingga kriteria dalam efektifitas penerimaan PBB-P2 pada tahun 2016 Efektif. Pada tahun 2017 pemerintah sangat antusias dalam masyarakat membayar pajak sehingga pemerintah menurunkan Target efektiitas penerimaan dan realisasi pada tahun 2017 sangat efektif karena persentasenya $129,73 \%$.

Tabel 6. Efektivitas Pendapatan PBB-P2 Kota Manado Tahun 2015-2017

\begin{tabular}{cccrl}
\hline Tahun & $\begin{array}{c}\text { Target } \\
(\mathbf{R p})\end{array}$ & $\begin{array}{c}\text { Realisasi } \\
(\mathbf{R p})\end{array}$ & $\begin{array}{c}\text { Persentase } \\
(\boldsymbol{\%})\end{array}$ & Kriteria \\
\hline 2015 & $31.210 .524 .776,00$ & $28.740 .333 .816,00$ & $92,08 \%$ & Efektif \\
2016 & $30.000 .000 .000,00$ & $24.467 .264 .925,00$ & $81,55 \%$ & Cukup efektif \\
2017 & $24.534 .660 .000,00$ & $27.710 .018 .490,00$ & $112,94 \%$ & Sangat efektif \\
& Rata-rata & & $95,52 \%$ & Efektif \\
\hline
\end{tabular}

(Sumber: Data Badan Pengelola Pajak dan Retribusi Daerah Kota Manado)

Berdasarkan tabel 6 ukuran efektifitas pada pendapatan PBB Perdesaan dan Perkotaan (PBB-P2) dari tahun 2015-2017 yaitu 95,52\% yang dikatagorikan efektif. Di tahun 2015 pelaksanaan PBB-P2 tahun 2015 targetnya tidak melewati prosedur yang telah diatur yaitu sebesar 92,08\% karena setelah PBB-P2 di serahkan kepada daerah pemerintah belum memberikan vasilitasi kepada masyarakat tentang bagaimana membayar pajak dengan baik. Tetapi itu hanya sebagian kecil dari masyarakat karna sebagian besar masyarakat sudah mengerti bagaimana dan apa kegunaan kita dalam membayar pajak. Pada tahun 2016 pemerintah menurunkan target efektitas penerimaan PBB-P2 sehingga persentase pada tahun 2016 yaitu 81,55\% dalam kriteria cukup efektif. Pada tahun 2015 ke 2016 terjadi penurun persentase di karenakan masyarakat yang ada di daerah Kecamatan Singkil mengalami kesulitan dalam membayar pajak bumi dan bangunan di karenakan banyak masyarakat yang tidak menerima SPPT. Pada tahun 2017 pemerintah menurunkan target penerimaan dan realisasi yang didapat sangat di luar dugaan karna Sangat Efektif penerimaan PBB perdesaan dan perkotaan ditahun 2017 dengan persentase 112, 94\%. Dikarenakan Pemerintah sudah sangat bekerja keras sehingga masyarakat sudah paham dan mengerti tentang membayar pajak tepat waktu.

\section{Kontribusi PBB-P2 Terhadap PAD Kabupaten Minahasa Selatan dan Kota Manado}

Tabel 7. Kontribusi Pajak Bumi dan Bangunan Perdesaan dan Perkotaan (PBB-P2) terhadap Pendapatan Asli Daerah (PAD) Kabupaten Minahasa Selatan tahun 2015-2017

\begin{tabular}{ccccc}
\hline Tahun & $\begin{array}{c}\text { Realisasi PBB-P2 } \\
(\boldsymbol{\%})\end{array}$ & $\begin{array}{c}\text { Realisasi PAD } \\
(\mathbf{R p})\end{array}$ & $\begin{array}{c}\text { Persentase } \\
(\boldsymbol{\%})\end{array}$ & Kriteria \\
\hline 2015 & 1.183 .675 .827 & 26.137 .234 .620 & $4,52 \%$ & SK \\
2016 & 2.379 .297 .962 & 32.567 .773 .521 & $7,30 \%$ & SK \\
2017 & 674.609 .264 & 36.406 .092 .809 & $1,85 \%$ & SK \\
& Rata-rata & & $4,55 \%$ & SK \\
\hline
\end{tabular}

(Sumber: Data Badan Pengelola Pajak dan Retribusi Daerah Kabupaten Minahasa Selatan)

Ket: SK (Sangat Kurang)

Berdasarkan tabel 7 Menunjukan bahwa kontribusi PBB Perdesaan dan Perkotaan pada tahun 2015-2017 sangat kurang sebesar 4,55\% dikarenakan belum maksimal pemerintah 
Kabupaten Minahasa Selatan. Tahun 2015 kontribusi PBB-P2 sebesar 4,52\% menyatakan untuk kontribusi PBB-P2 kepada PAD tetap termasuk sangat kurang karena kurangnya pemerintah dalam mengoptimalkan sumber-sumber penerimaan PBB-P2. Pada tahun 2016 terjadi peningkatan sebesar 7,30\% dari tahun sebelumnya dikarenakan Pemerintah daerah mulai berupayah memajukan tingkat kontribusi dengan berbagai cara salah satunya melakukan pembaharuan data dan mencari potensi-potensi baru dan memunculkan objekobjek wisata baru di daerah Minahasa Selatan. Pada tahun 2017 kontribusi PBB perdesaan dan perkotaan turun menjadi 1, 85\%. Kontribusi PBB-P2 yang memusut dikarenakan perkembangan pada pendapatan asli daerah lebih laju pertumbuhannya dibandingkan Pajak bumi dan bangunan perdesaan dan perkotaan. Pemerintah memandang bahwa penerimaan PBB-P2 belum penting sehingga pendapatan PBB-P2 tidak maksimal sehingga membuat hasil dari penerimaan belum optimal.

Tabel 8. Kontribusi Pajak Bumi dan Bangunan Perdesaan dan Perkotaan (PBB-P2) terhadap Pendapatan Asli Daerah (PAD) Kota Manado Tahun 2015-2017

\begin{tabular}{cccrc}
\hline Tahun & $\begin{array}{c}\text { Realisasi PBB-P2 } \\
(\mathbf{R p})\end{array}$ & $\begin{array}{c}\text { Realisasi PAD } \\
(\mathbf{R p})\end{array}$ & $\begin{array}{c}\text { Persentase } \\
(\boldsymbol{\%})\end{array}$ & Kriteria \\
\hline 2015 & 28.740 .333 .816 & 263.392 .296 .958 & $10,91 \%$ & Kurang \\
2016 & 24.467 .264 .925 & 289.462 .741 .463 & $8,45 \%$ & Sangat kurang \\
2017 & 27.710 .018 .490 & 306.453 .382 .648 & $9,04 \%$ & Sangat kurang \\
& Rata-rata & & $9,46 \%$ & Sangat kurang \\
\hline
\end{tabular}

(Sumber: Data Badan Pengelola Pajak dan Retribusi Daerah Kota Manado)

Berdasarkan tabel 8 memperlihatkan untuk kontribusi pada PBB Perdesaan serta Perkotaan untuk PAD Kota Manado memiliki perhitungan dari tahun 2015 sampai dengan tahun 2017 yaitu sebesar 9,46\%, berdasarkan patokan atau indikator yang ada penilaiannya yaitu sangat kurang. Hal ini menunjukan untuk kontribusi Pajak Bumi dan Bangunan Perdesaan dan Perkotaan sangat kurang terhadap Pendapatn Asli Daerah (PAD) Kota Manado. Di tahun 2015 kontribusi PBB-P2 sebesar 10,91\% menunjukan bahwa kontribusi PBB-P2 terhadap PAD masih terbilang minim karena kurangnya pemerintah dalam memaksimalkan sumber-sumber penerimaan PBB-P2. Pada tahun 2016 kontribusi PBB-P2 menurun sebesar $8,45 \%$ karena pertumbuhan persentase pendapatan asli daerah lebih banyak dari pertumbuhan Pajak bumi dan bangunan perdesaan dan perkotaan. Pada tahun 2017 kontribusi PBB-P2 naik sebesar 9,04\% dikarenakan pemerintah daerah mulai mendata kembali dan menggali potensi baru melalui pendataan. Juga pemerintah melakukan sosialisasi sehingga sudah tidak ada lagi masyarakat terlambat membayar pajak.

\subsection{Pembahasan}

Efektivitas pada Pajak Bumi dan Bangunan Perdesaan dan Perkotan (PBB-P2) menunjukan bahwa Kota Manado sebesar 95,52\% (Efektif) lebih tinggi dibandingkan Minahasa Selatan 88,12\% (cukup efektif). Ini menunjukan Kota Manado dalam efektifitas PBB-P2 selama tiga tahun terakhir lebih baik dibandingkan dengan Kabupaten Minahasa Selatan. Pada tahun 2015 Kabupaten Minahasa Selatan saat adanya pengalihan PBB-P2 menjadi Pajak Daerah menunjukan bahwa realisasi Pajak Bumi dan Bangunan Perdesaan dan Perkotaan jauh di atas target yang ditentukan, dimana dalam tahun 2015 tingkat keefektifitasnya digolongkan tidak efektif sedangkan pada tahun 2016 tingkat keefektifitasnya naik menjadi efektif. Dengan adanya pengalihan Pajak Bumi dan Bangunan Perdesaan dan Perkotaan dari pajak pusat menjadi pajak daerah, Pemerintah Minahasa Selatan dan Kota Manado perlu menyiapkan perangkat pengolahan mengingat PBB-P2 masih terbilang pajak daerah yang baru dialihkan. Dengan meninjau potensi yang ada dari setiap 
kabupaten/kota bias terjadi peningkatan setiap tahunnya dengan adanya pendataan ulang. Pemerintah dari setiap kabupaten/kota harus memberikan sosialisasi kepada masyarakat atau wajib pajak agar kesadaran akan membayar PBB-P2 dapat dijalankan. Harapan pada realisasi yang melampaui target yang ditetapkan akan meningkatkan pendapatan daerahnya sendiri. Namun masih ada factor yang menghambat pelaksanaan pemungutan PBB-P2 dari setiap kabupaten/kota, seperti kurangnya kesadaran membayar pajak sari wajib pajak sendiri, dan perangkat yang bertanggung jawab dalam pengolahan perlu diperbaiki seperti pendataan kepada objek pajak dan subjek pajak dengan turun langsung dan menilai kembali di lapangan agar penerimaan dan pendapatan PBB-P2 semakin efektif.

Kontribusi dalam menerima Pajak Bumi dan Bangunan Perdesaan dan Perkotaan pada Pendapatan Asli Daerah yang digambarkan dalam tabel 4.8 menunjukkan bahwa Minahasa Selatan lebih rendah dengan persentase 4,55\% (sangat Kurang) sedangkan Kota Manado sebesar 9,46\% (sangat kurang). Ini membuktikan bahwa Kabupaten Minahasa Selatan dan Kota Manado belum maksimal dalam pengelolahan PBB-P2, kurangnya pemanfaatan dan mengoptimalkan pendapatan yang termasuk dalam objek pajak PBB-P2 dengan adanya factor lain yang mempengaruhi kurangnya kontribusi PBB-P2 dalam Pendapatan Asli Daerah. Pemerintah Kabupaten Minahasa Selatan dan Kota Manado harusnya lebih mengusahakan pungutan terhadap PBB-P2, supaya bisa memberikan kontribusi yang tetap meningkat ditahun selanjutnya. Dengan adanya kerjasama dengan pihak-pihak yang terkait dalam pelaksanaan pemungutan, dan pengelolaan PBB-P2. Seperti adanya objek tapi tidak memiliki objek. Banyaknya data yang tidak akurat dan tidak sesuai dengan kondisi lapangan yang sebenarnya sehingga penerimaan yang kurang optimal. Selain itu, kurangnya kesadaran wajib pajak dalam membayar PBB-P2 juga menjadi factor penghambat untuk meningkatkan penerimaan PBB-P2.

\section{KESIMPULAN DAN SARAN}

\subsection{Kesimpulan}

Berdasarkan hasil penelitian dan pembahasan pada bab sebelumnya, maka kesimpulannya, antara lain:

1. Efektivitas Pajak Bumi dan Bangunan dan Perkotaan digambarkan dalam hasil penelitian Kota Manado 95,52\% (efektif) lebih tinggi dari Kabupaten Minahasa Selatan 88,12\% (cukup efektif). Hasil penelitian ini menunjukan bahwa Kota Manado dan Kabupaten Minahasa memiliki pertumbuhan yang baik.

2. Kontribusi dalam pendapatan Pajak Bumi dan Bangunan Perdesaan dan Perkotaan pada Pendapatan Asli Daerah Kabupaten Minahasa Selatan 4,55\% (sangat kurang), dan Kota Manado 9,46\% (sangat kurang). Hasil penelitian tersebut menunjukkan bahwa Pemerintah Kabupaten Minahasa Selatan dan Kota Manado masih sangat kurang optimal dalam pengelolaan PBB-P2 sebagai sumber pendapatan bagi daerahnya masing-masing.

\subsection{Saran}

Berdasarkan hasil penelitian dan pembahasan serta kesimpulan tersebut, maka penulis memberikan saran, antara lain:

1. Untuk Pemerintah Kabupaten Minahasa Selatan sebaiknya supaya ditingkatkan pendapatan Pajak Bumi dan Bangunan Perdesaan dan Perkotaan (PBB-P2). Pemerintah Kabupaten Minahasa Selatan baiknya harus mengekstensifikasi PBB-P2, mencari potensi baru di bidang PBB-P2, sehingga lebih meningkatkan kontribusi terhadap PAD di tahun selanjutnya.

2. Buat pemerintah Kota Manado harusnya supaya meningkatkan pendapatan PBB-P2, dengan memberikan penyuluhan atau konseling sesuai aturan untuk masyarakat dan hal ini WP mengenai sadarnya membayar pajak terlebih PBB-P2 dikarenakan secara tidak langsung realisas oleh pajak dengan sangat bermanfaat untuk masyarakat nantinya, 
ditingkatkan lagi kerja pelayanan untuk saat penerimaan pajak, dan perlunya melakukan penilaian dan pengolahan data ulang, serta mengektensifikasi potensi baru di bidang PBB-P2. Upaya ekstensifikasi potensi baru di bidang PBB-P2. Upaya ekstensifikasi pajak dapat dilakukan dengan cara memperluas wajib pajak, penyempurnaan tariff, dan perluasaan objek pajak, sehingga baik efektifitas maupun kontribusi PBB-P2 terhadap PAD dapat lebih ditingkatkan lagi.

3. Untuk pemerintah Kabupaten Minahasa Selatan dan Kota Manado agar mensosialisasikan kepada masyarakat batas akhir pembayaran pajak PBB-P2 tanggal 30 September.

\section{DAFTAR PUSTAKA}

Agoes, Sukrisno. Trisnawati, Estralia. 2013. Akuntansi Perpajakan. Edisi ke-3. Salempa Empat. Jakarta.

Mardiasmo. 2016. Perpajakan. Edisi Refisi. Andi. Yogyakarta.

Napitupul. 2017. Pajak Bumi dan Bangunan Perdesaan dan Perkotaan (PBB-P2) sebagai Pajak Daerah dan Implikasinya Terhadap Pencatatan Akuntansi Pada Pemerintah Kota Manado. Skripsi. Universitas Sam Ratulangi Manado.

Nurmala sari, 2014. Analisis Efektivitas dan Kontribusi Proses Pelayanan Pengalihan Pengelolaan Serta Pemasukan PBB-P2 Terhadap Pendapatan Daerah. Jurnal Ilmiah. Jurusan Ilmu Ekonomi. Fakultas Ekonomi dan Bisnis Brawijaya Malang. Malang.

Pemerintah Republik Indonesia. 2009. Undang-undang Nomor 28 Tahun 2009. Tentang Pajak Daerah dan Retribusi Daerah.

Pemerintah Republik Indonesia. 2009. Undang-undang Nomor 16 Tahun 2009. Tentang Ketentuan Umum dan Tata Cara Perpajakan.

Riyono dan Sodikin. 2014. Akuntansi Pengantar 1. UPP STIM YKPN. Yogyakarta. Rudianto. 2014. Akuntansi Manajemen. Erlangga. Jakarta.

Sadeli, 2016. Dasar-dasar Akuntansi. Bumi Aksara. Jakarta.

Sari Diana, 2013. Konsep Dasar Perpajakan. Refika Aditama. Bandung.

Samudra, A.A. 2015. Perpajakan di Indonesia. PT Raja Grafindo Persada. Jakarta. Warren Carl. 2015. Pengantar Akuntansi 2. Salemba Empat. Jakarta. 